\title{
FAKTOR-FAKTOR URBANISASI DI INDONESIA
}

\author{
Millary Agung Widiawaty \\ Pendidikan Geografi UPI / 1607783 / millary@ student.upi.edu
}

\section{A. Pendahuluan}

Urbanisasi merupakan proses yang terjadi akibat laju pertumbuhan penduduk yang tinggi, mobilitas demografis dari daerah pedesaan menuju perkotaan terutama yang dapat menyebabkan perluasan fisik wilayah kota [1][2]. Pertumbuhan penduduk yang tinggi menyebabkan kebutuhan akan sumberdaya alam meningkat, terutama kebutuhan lahan [3]. Konversi lahan dapat memicu perkembangan wilayah pinggiran kota dan wilayah pedesaan di sekitarnya. Perubahan dalam struktur sosial dan pola spasial di pinggiran kota menandakan munculnya pusat layanan baru. Pertumbuhan wilayah perkotaan mengubah daerah pertanian dan karakteristik sosial dan ekonomi [4]. Pada tahun 1900, populasi penduduk dunia yang tinggal di kawasan perkotaan hanya sebesar 15 persen, sementara itu pada abad ke-20 pertumbuhan populasi perkotaan melaju sangat pesat dan diperkirakan akan terus meningkat [5]. Indonesia merupakan salah satu negara yang mengalami lonjakan penduduk yang sangat pesat, hal tersebut berdampak pada meningkatnya mobilitas penduduk. Selama kurun waktu 50 tahun terakhir (1968-2018), perkembangan urbanisasi cukup signifikan. Pada tahun 1971 penduduk kota memiliki presentase sebesar 17,2 persen. Hingga tahun 2018, angka terus mengalami peningkatan [6]. Mobilitas penduduk desa menuju kawasan perkotaan dipicu karena kota memiliki daya tarik seperti tersedianya berbagai fasilitas pendidikan, heterogenitas lapangan pekerjaan, hiburan dan berbagai fasilitas lainnya. Sementara itu, kawasan pedesaan yang cenderung homogen dengan ditandai sulitnya lapangan pekerjaan yang tersedia, dan minim fasilitas penunjang. Tujuan dari penelitian ini yaitu untuk menganalsis berbagai faktor urbanisasi di Indonesia. Data terkait penduduk diperoleh dari sumber sekunder yang relevan.

\section{B. LITERATUR REVIEW}

\section{Urbanisasi}

Urbanisasi merupakan suatu fenomena bertambahnya jumlah penduduk di perkotaan sejalan dengan tingkat kesejahteraan dan perkembangan ekonomi penduduk di suatu negara. Secara sederhana urbanisasi didefinisikan sebagai perpindahan penduduk dari kawasan perdesaan menuju kawasan perkotaan [7]. Urbanisasi banyak dipengaruhi oleh proses alami yang meliputi 
angka kelahiran, dan kematian, bencana alam, perubahan lingkungan serta masalah sosial-ekonomi yang meliputi pendapatan individu, pendidikan, kesehatan, fasilitas dasar, industrialisasi dan kebijakan pemerintah [8][9].

\section{Faktor Urbanisasi}

Terdapat faktor yang menyebabkan terjadinya urbanisasi yang meliputi faktor penarik dan pendorong. Faktor penarik merupakan kondisi yang menyebabkan seseorang tertarik untuk pindah ke kawasan perkotaan karena terdapat daya tarik yang ditawarkan. Faktor pendorong terdiri atas fasilitas kesehatan yang memadai, standar hidup yang tinggi, standar pendidikan yang tinggi, fasilitas rekreasi, kesempatan kerja, keamanan kehidupan dan properti yang lebih baik dan lingkungan sosial yang lebih baik. Sedangkan faktor pendorong merupakan faktor yang menyebab seseorang pindah ke kawasan perkotaan karena kondisi perdesaan yang sudah tidak mendukung. Faktor pendorong meliputi kemiskinan, standar hidup yang rendah, keamanan hidup yang rendah, minim fasilitas transportasi dan komunikasi, kurangnya lapangan pekerjaan, minim fasilitas kesehatan, kualitas pendidikan yang rendah [10][11][12]

\section{METODE}

Penelitian ini tergolong penelitian studi kepustakaan karena mencoba mengumpulkan sejumlah informasi dari berbagai sumber relevan yang selanjutnya dilakukan analisis secara mendalam. Data-data yang diperlukan meliputi data sosial yang terdiri atas pendapatan penduduk, angka kelahiran, kematian, dan migrasi. Data tersebut diperoleh dari berbagai sumber sekunder seperti Badan Pusat Statistik guna memperoleh data tren perubahan penduduk Indonesia, sementara itu untuk memperoleh besaran produk domestik bruto diperoleh dari Bank Indonesia dan World Bank. Data infrastruktur diperoleh dari Kementrian Keuangan. Selanjutnya data pembanding diperoleh dari website resmi Kementrian Perdagangan, Departemen Kesehatan, dan Bappenas serta data jumlah korban bencana alam diperoleh dari BNPB dan BPBD.

\section{HASIL DAN PEMBAHASAN}

\section{Proses Alami dan Migrasi}

Proses alami meliputi jumlah kelahiran dan kematian di suatu negara. Berdasarkan proyeksi penduduk yang dikeluarkan oleh Bappenas yakni angka angka kelahiran pada 2035 menunjukkan penurunan, sementara itu tingkat kematian mengalami kenaikan. Jumlah penduduk Indonesia tahun 2010 sebesar 238,52 juta jiwa, dengan jumlah kelahiran mencapai 5 juta jiwa. 
Sedangkan angka kematian sebesar 1,52 juta jiwa. Jumlah penduduk Indonesia pada 2011 mengalami peningkatan menjadi 242 juta jiwa. Pada tahun 2019 jumlah penduduk Indonesia mengalami peningkatan sebesar 10,29 persen, yaitu jumlah penduduk Indonesia mencapai 266,91 jiwa selama kurun waktu 8 tahun. Berdasarkan proyeksi tersebut, pada tahun 2035 tingkat kelahiran terus menunjukkan penurunan menjadi 4,29 juta jiwa. Kondisi berbeda ditunjukkan dengan meningkatnya angka kematian hingga mencapai 2,68 juta jiwa [13].

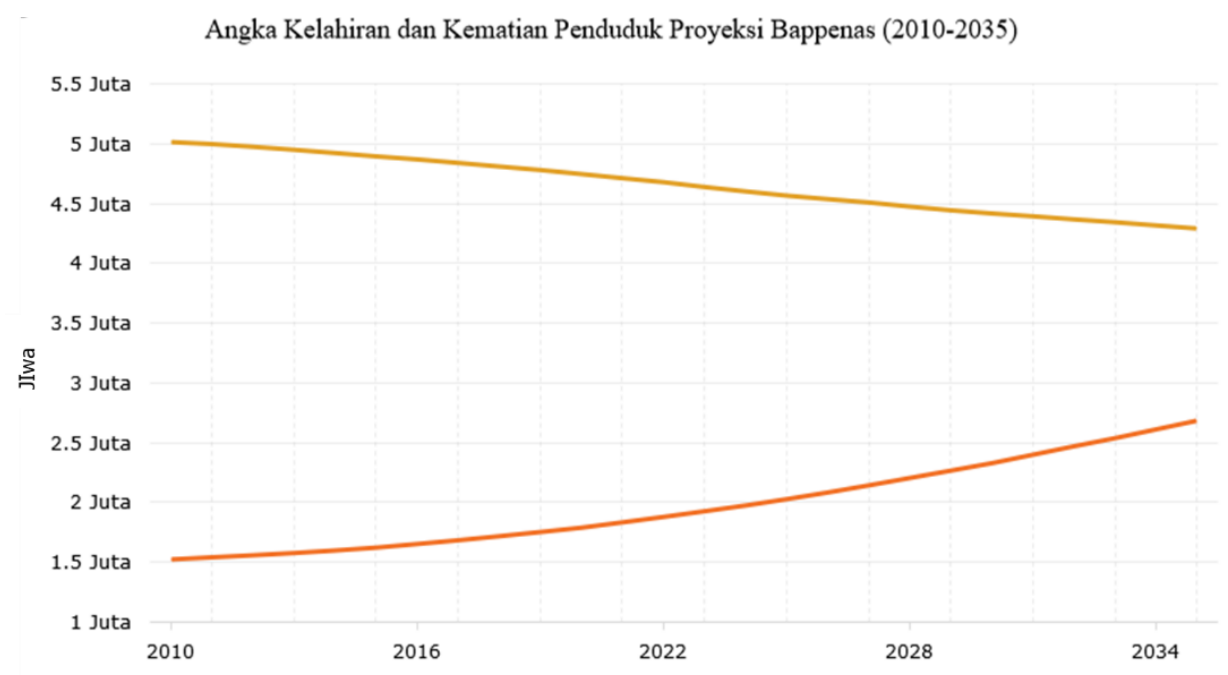

Gambar 1. Angka Kelahiran dan Kematian Sumber: Bappenas, 2019

Kematian dapat disebabkan akibat bencana alam yang terjadi. Sepanjang tahun 2018-2019, jumlah korban meninggal dan hilang akibat bencana alam mencapai 4814 jiwa. Provinsi Sulawesi Tengah merupakan wilayah dengan jumlah koban tertinggi yakni 3474 jiwa. Kematian korban di Sulawesi Tengah terjadi akibat bencana gempa maupun tsunami pada 28 September 2018. Jumlah korban meninggal dan hilang teringgi kemudian disusul oleh Provinsi Nusa Tenggara Barat akibat gempa bumi pada Juli 2018, Lampung dan Banten akibat tsunami yang terjadi pada 22 Desember 2018 yakni mencapai 470 jiwa. 


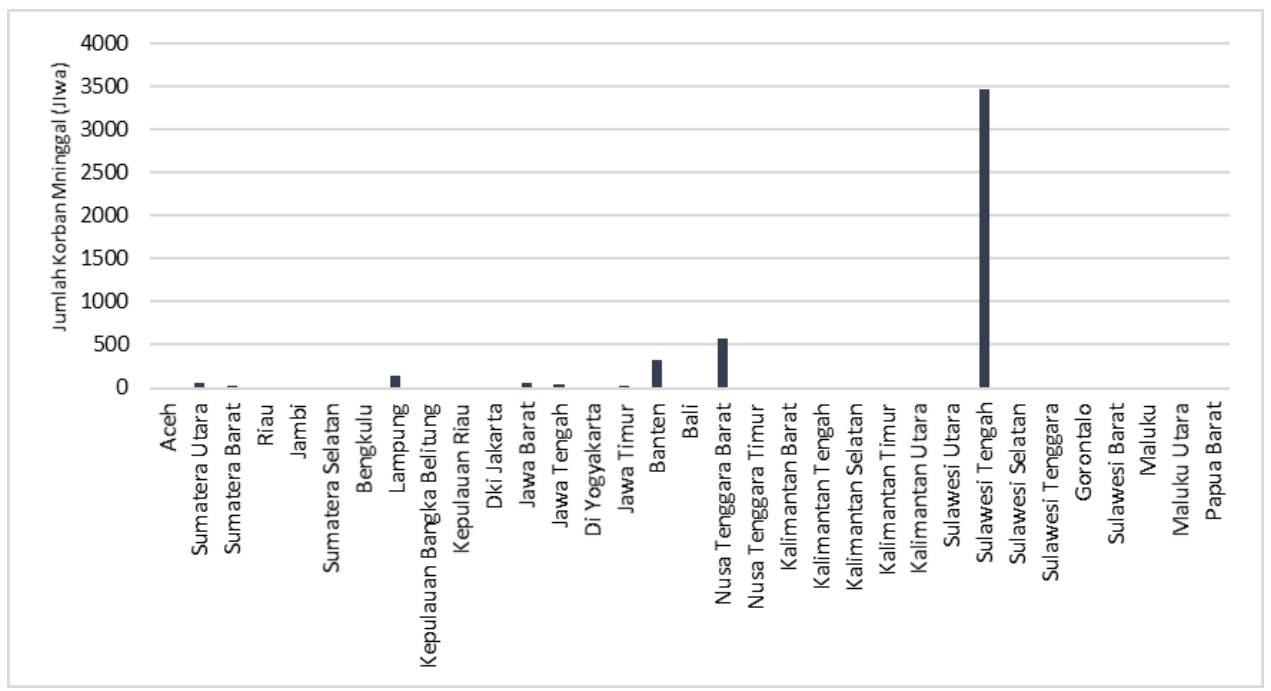

Gambar 2. Jumlah Korban Jiwa Akibat Bencana Alam Tahun 2018-2019 Sumber: Diolah dari BNPB, 2019

Migrasi penduduk menyebabkan bertambah dan berkurangnya jumlah penduduk pada suatu wilayah. Bentuk migrasi di Indonesia yang paling nampak yakni urbanisasi. Proporsi jumlah penduduk kota di Indonesia terus mengalami peningkatan. Persentase penduduk kota Jakarta telah mencapai 100 persen, sementara itu, proporsi tertinggi disusul Provinsi Kepulauan Riau yang mencapai 83,18 persen penduduk tinggal di kawasan perkotaan. Sedangkan Pulau Jawa bagian Barat, Yogyakarta, Bali, Kalimantan Utara dan Kalimantan Timur tergolong dalam jumlah penduduk kota yang tinggi dengan rentang 61 persen hinga 80 persen. Kota-kota di provinsi tersebut menjadi pilihan penduduk desa untuk meningkatkan standar dan kulitas hidup.

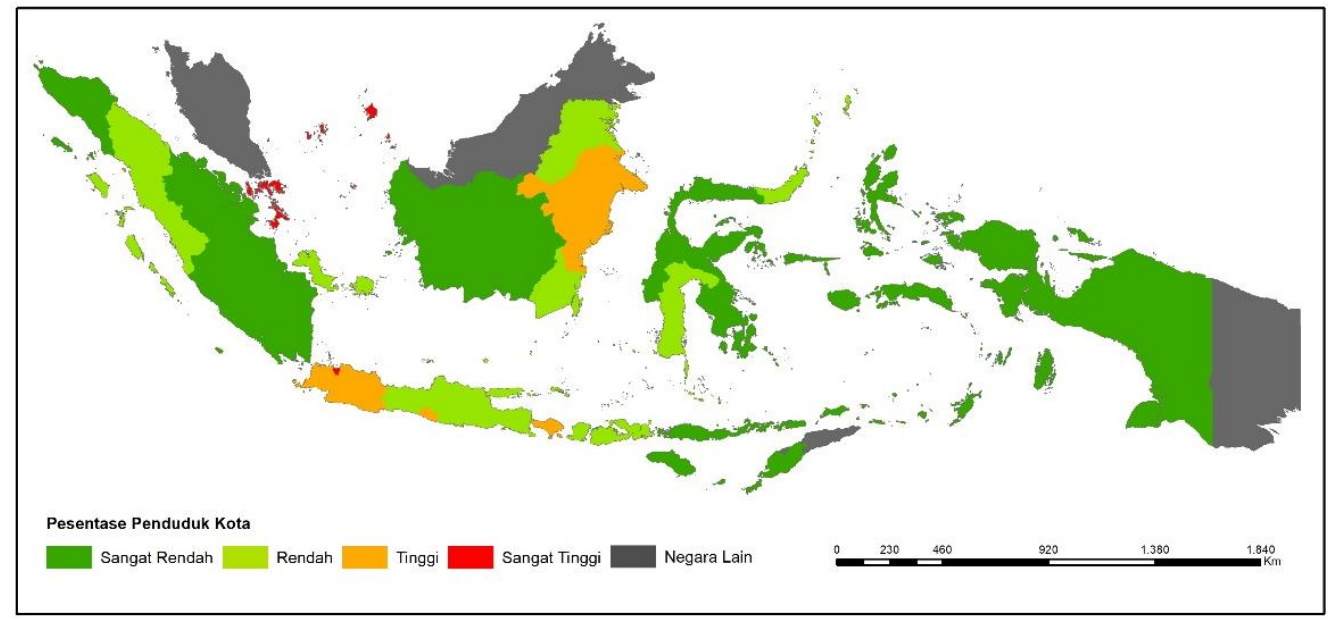

Gambar 3. Peta Persentase Jumlah Penduduk Kota Setiap Provinsi Tahun 2019 Sumber: Diolah dari BPS, 2017 


\section{Kondisi Ekonomi}

Faktor pendorong penduduk desa melakukan urbanisasi karena minimnya lapangan pekerjaan di daerah asal. Pertanian menjadi sector utama yang diandalkan oleh penduduk, sementara itu angka kelahiram semakin meningkat yang menyebabkan tidak terpenuhinya kebutuhan. Kemiskinan di desa menjadi faktor pendorong penduduk desa untuk bermigrasi. Terdapat kaitan antara meningkat dan menurunnya PDB suatu negara dengan tingkat urbanisasi. Bila ditinjau dari perspektif ekonomi, proses urbanisasi mampu meningkatkan produktifitas dan efisiensi yang lebih besar dalam alokasi sumber daya nasional. Meskipun, di sisi lain urbanisasi dapat menjadi beban fiskal tambahan terkait perbaikan infrastrukur [14].

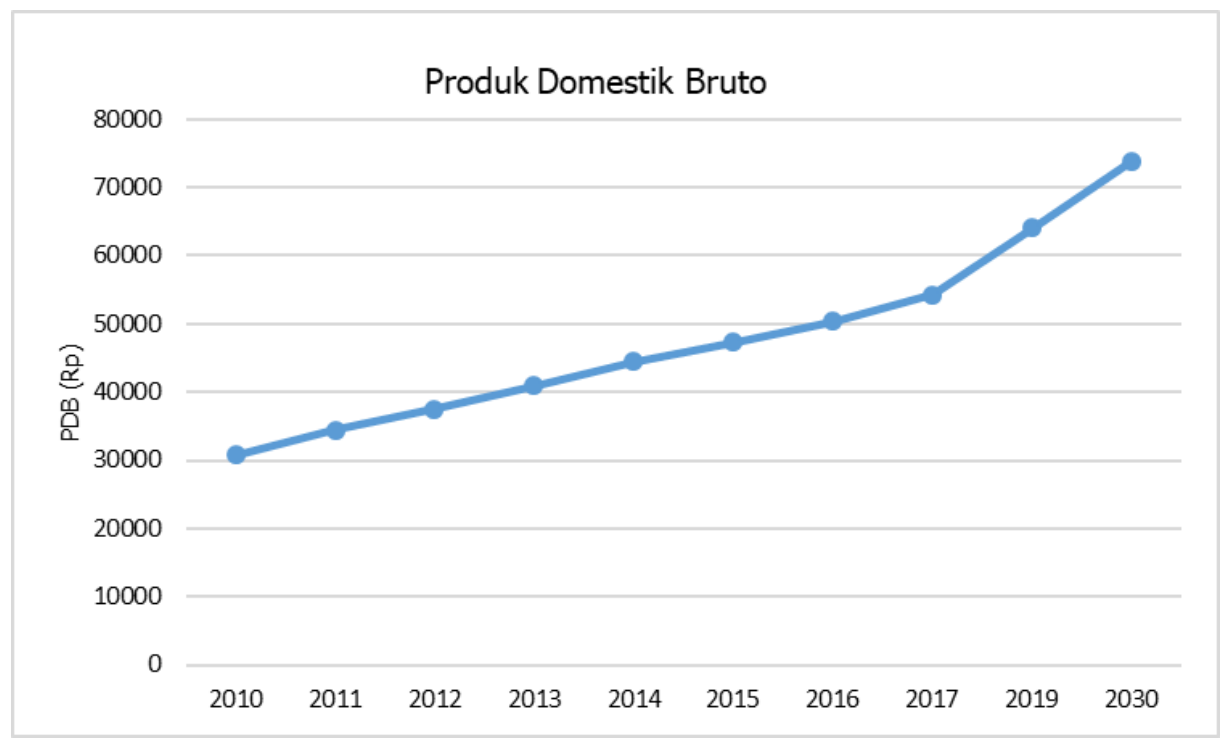

Gambar 4. Pertumbuhan Ekonomi Indonesia Sumber: Diolah dari BPS, 2019

Berdasarkan data yang dirilis BPS Produk Domestik Bruto (PDB) Indonesia sepanjang tahun 2010 hingga 2019 mengalami pertumbuhan. Sejak 1961, ekonomi Indonesia secara umum mengalami pertumbuhan dan hanya dua kali mengalami kontraksi. Pertumbuhan PDB Indonesia tertinggi terjadi pada tahun 1968, yakni mencapai 10,92 persen. Sementara pada era reformasi, pertumbuhan ekonomi tertinggi dicatat pada 2007, yakni mencapai 6,35 persen. Namun, ekonomi Indonesia pernah mengalami pertumbuhan negatif, yaitu pada tahun 1963 di era Orde Lama dan pada 1998 saat terjadi krisis finansial Asia. Sementara itu, berdasarkan hasil proyeksi pada tahun 2030 PDB Indonesia akan mengalami peningkatan yang cukup signifikan. 


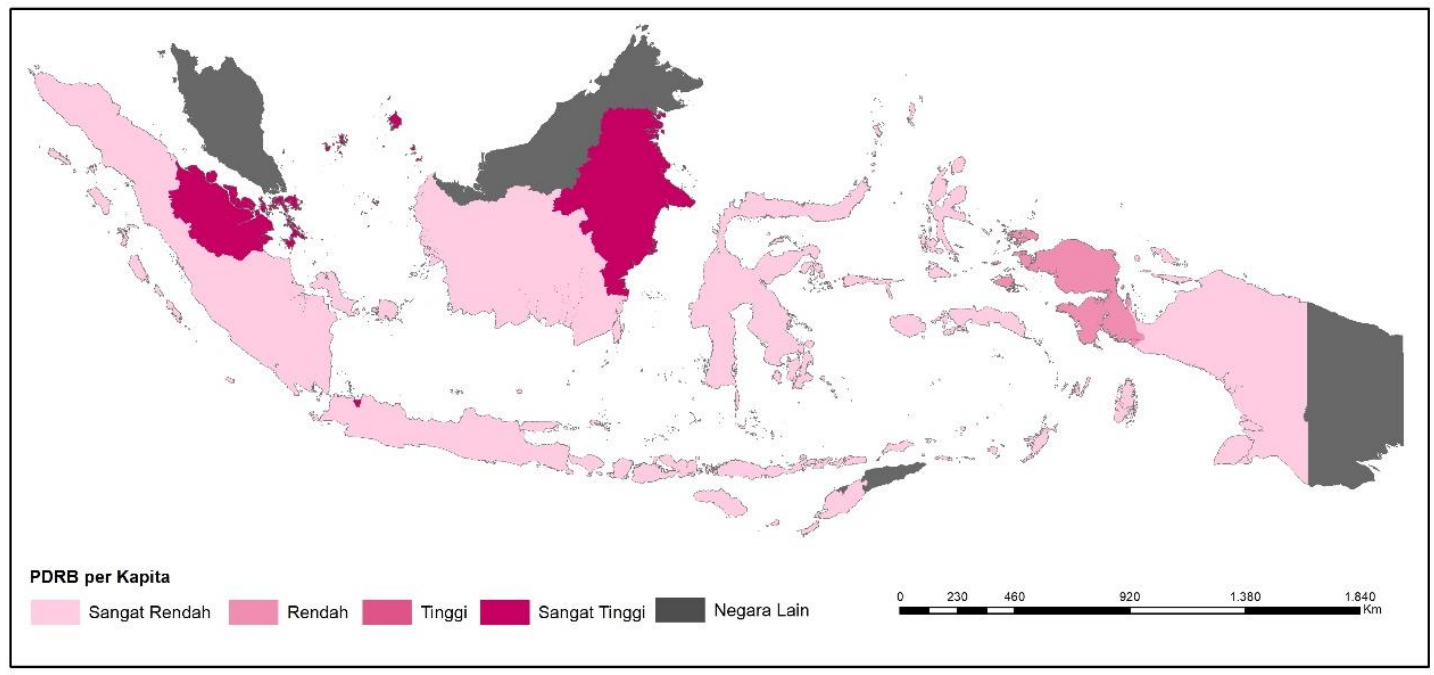

Gambar 5. PDRB per Kapita Negara Indonesia Sumber: Diolah dari BPS, 2018

Provinsi DKI Jakarta merupakan wilayah dengan angka PDRB tertinggi di Indonesia yakni mencapai RP 232342 juta, disusul oleh Kalimantan Timur, Kalimantan Utara dan Kepulauan Riau. Sementara itu, Provinsi Nusa Tenggara Timur merpakan wilayah dengan PDRB terendah.

\section{Fasilitas Sosial-Ekonomi dan Urbanisasi}

Fasilitas yang memadai menjadi daya tarik penduduk desa melakukan urbanisasi menuju kawasan perkotaan. Fasilitas pendidikan yang memadai menjadi alasan penduduk melakukan migrasi. Salah satu capaian pembangunan Indonesia yakni meningkatnya Indeks Pembangunan Manusia (IPM) yang ditandai dengan kemudahan mengakses hasil pembangunan dalam memperoleh pendidikan yang layak, pendapatan, dan layanan kesehatan. Kurun waktu empat tahun terakhir, tren IPM Indonesia terus mengalami peningkatan. Peningkatan Indeks Pembangunan Manusia dari 68,9 tahun 2014, menjadi 70,81 pada tahun 2017, dengan demikian angka tersebut termasuk dalam kategori "tinggi" yakni memposisikan negara Indonesia pada urutan ke-116 dari 189 negara [15]

Tabel 1. Perkembangan Jumlah Sekolah berdasarkan Jenjang

\section{\begin{tabular}{|l|l|l|l}
\hline Jenjang & $2016 / 2017$ & $2017 / 2018$ & Pertumbuhan
\end{tabular}}

\begin{tabular}{|c|r|r|r|}
\hline SD & 147503 & 148244 & 0,5 \\
\hline SMP & 37763 & 38960 & 3,17 \\
\hline SMA & 13144 & 13495 & 2,67 \\
\hline SMK & 13236 & 13710 & 3,58 \\
\hline
\end{tabular}

Sumber: Kementrian Pendidikan dan Kebudayaan 
Tabel 1 menunjukkan perkembangan jumlah sekolah setiap jenjang pendidikan selama dua tahun terakhir. Terjadi peningkatan jumlah sekolah pada jenjang pendidikan menengah, yaitu SMK mencapai 3,58 persen dan SMP sebesar 3,17 persen. Pelayanan sekolah terus diperbaiki agar tingkat melek huruf semakin membaik.

\section{Aksesibilitas menuju Fasilitas Dasar}

Kemudahan akses menuju pelayanan dasar menjadi daya tarik penduduk untuk melakukan urbanisasi. Ketersediaan air bersih, sanitasi yang layak, dan listrik menjadi faktor pertimbangan penduduk untuk bermukim. Gambar 6. menunjukkan persentase rumah tangga dengan akses air minum layak, sanitasi dan listrik. Sepanjang tahun 2014-2019 terjadi peningkatan akses rumah tangga terhadap berbagai fasilitas dasar.

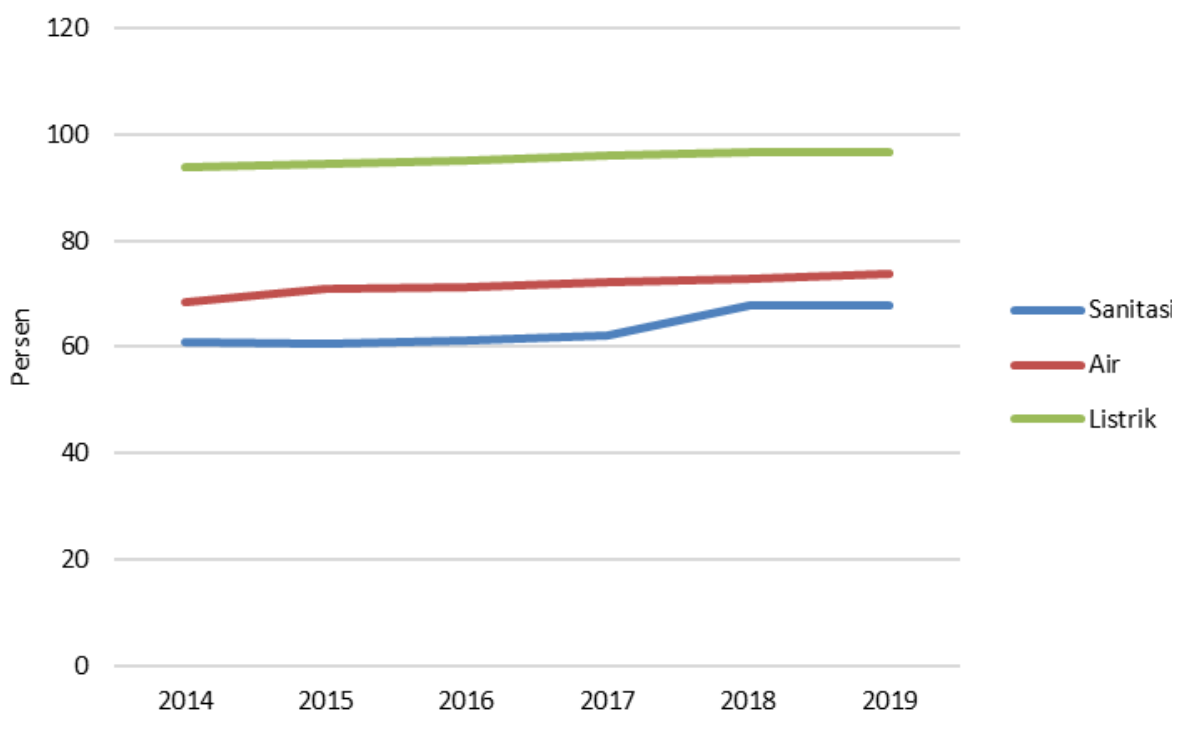

Gambar 6. Akses menuju Pelayanan Dasar Sumber: Diolah dari BPS, 2019

Persentase wilayah perkotaan untuk Provinsi Jawa dan Bali, sebagian Sumatera, dan Papua tergolong lebih rendah dalam mengakses air minum layak dibandingkan pada pedesaan. Begitu pula akses air bersih di wilayah tersebut lebih baik pada pedesaan. Hal ini mengindikasikan minimnya antisipasi dalam pengelolaan air bersih untuk wilayah dengan jumlah penduduk yang relatif besar seperti di Jawa dan wilayah dengan sumber daya alam melimpah yang menyebabkan pesatnya perkembangan penduduk dan aktivitas ekonomi seperti di Riau dan Papua [16]. 


\section{Perkembangan Infrastruktur}

Perkembangan infrastruktur merupakan aspek penting untuk mempercepat proses pembangunan nasional dalam menggerakan roda perekonomian. Ketersediaan infrastruktur seperti jalan, sarana transportasi, telekomunikasi, dan fasilitas publik menjadi bagian utama yang perlu diperhatikan. Terkait kondisi infrastruktur Indonesia yang cenderung kurang memadai, maka perlu dilakukan pembenahan guna mengurangi kesenjangan pendapatan yang berdampak pada PDB per kapita. Perbaikan infrastruktur berkontribusi dalam meningkatkan produktivitas yang diharapkan mampu mendukung pertumbuhan ekonomi jangka panjang. Infrastruktur memiliki peran penting dalam meningkatkan pertumbuhan ekonomi di suatu negara [17].

Tabel 3. Nilai dan Peringkat Infrastruktur Indonesia

\begin{tabular}{cccccc}
\multicolumn{2}{c}{$2015-2016$} & \multicolumn{2}{c}{$2016-2017$} & \multicolumn{2}{c}{$2017-2018$} \\
Nilai & Peringkat & Nilai & Peringkat & Nilai & Peringkat \\
4,2 & 62 & 4,2 & 60 & 4,5 & 52 \\
\multicolumn{4}{c}{ Sumber: The Global Competitiveness } \\
& \multicolumn{3}{c}{ Report }
\end{tabular}

Tabel 3 menunjukkan bahwa pemerintah tengah serius memperbaiki aspek infrastruktur dalam bebrapa tahun terakhir. Peringkat infrastruktur Indonesia semakin membaik yang mana mengalami peningkatan 10 peringkat dari 62 pada tahun 2015/2016 menjadi peringat 52 pada tahun 2017/2018. Pembangunan infrastruktur di berbagai daerah terus dilakukan guna meningkatkan investasi dan indeks daya saing negara Indonesia. Dana yang dialokasikan untuk pembangunan infrastruktur dapat memberikan dampak jangka panjang sebagai investasi dan aset negara [18]

\section{Industri dan Kebijakan Pemerintah}

Kebijakan pemerintah terkait pengembangan industri dilakukan guna menumbuhkan kegiatan usaha, memperluas lapangan kerja dan meningkatkan pendapatan penduduk. Pembangunan industri baru memicu perpindahan penduduk desa menuju kota. Berdasarkan data yang dikeluarkan oleh Kementrian Perindustrian, pada triwulan I tahun 2018 pertumbuhan industri pengolahan non-migas mengalami kenaikan yang cukup berarti, yakni sebesar 5,03 persen bila dibandingkan dengan pertumbuhan pada triwulan I tahun 2017 yakni sebesar 4,8 persen. Meskipun angka pertumbuhan pada triwulan I tahun 2018 lebih rendah apabila disandingkan dengan pertumbuhan industry triwulan IV tahun 2017 yang diakibatkan karena terjadinya penurunan 
kinerja sebagian industri non-migas yakni kelompok industri mengalami penurunan jumlah produksi [19].

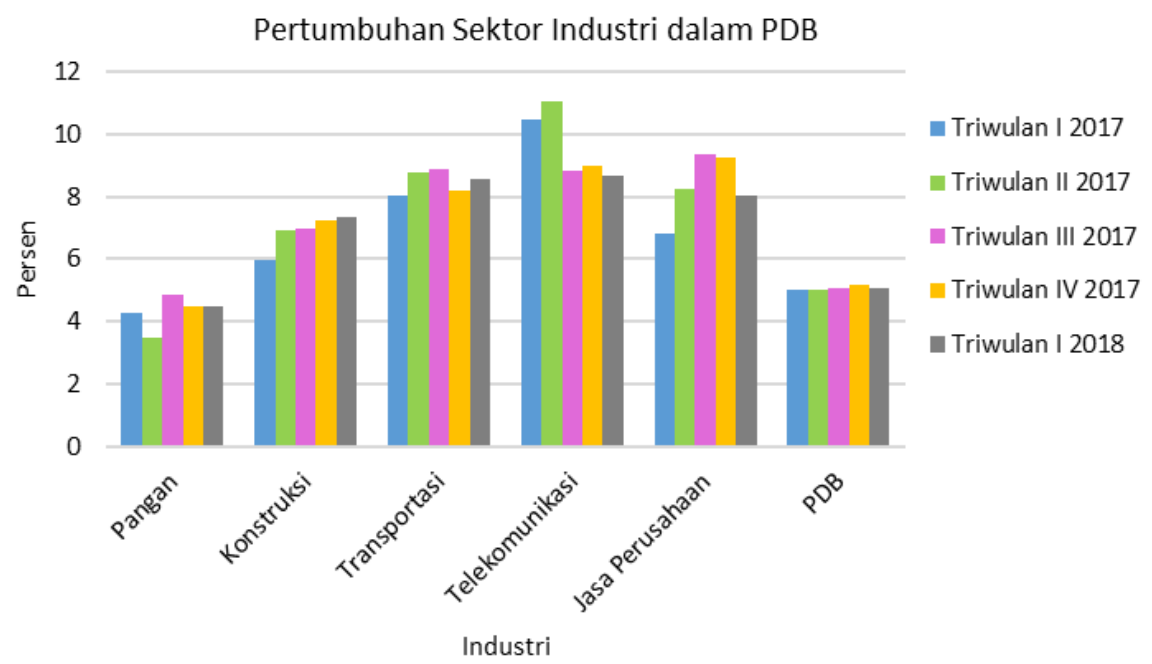

Gambar 7. Pertumbuhan Sektor Industri dalam PDB

Sumber: Diolah dari Kementrian Perindustrian, 2019

\section{E. KESIMPULAN}

Urbanisasi yang terjadi di Indonesia dipicu karena berbagai faktor baik berupa faktor pendorong yang meliputi kemiskinan, minimnya fadsilitas di pedesaan, standar hidup yang rendah, dan terbatasnya lapangan pekerjaan, serta faktor penarik yang meliputi fasilitas kota memadai dan standar hidup yang tinggi. Baik faktor pendorong maupun faktor penarik urbanisasi, keduanya terkait faktor tyang dipicu oleh proses alami, migrasi, kondisi ekonomi, fasilitas sosial-ekonomi, infrastruktur, aksesibilitas, indutri dan kebijakan pemerintah. Peningkatan mutu dan kualitas pada berbagai aspek tersebut dapat memicu terjadinya urbanisasi.

\section{F. REFERENSI}

[1] N. Malik, F. Asmi, and M. Ali, "Major Factors Leading Rapid Urbanization in China and Pakistan : A Comparative Study”, 2017.

[2] M. A. Widiawaty, M. Dede, and A. Ismail, "Analisis Tipologi Urban Sprawl di Kota Bandung Menggunakan Sistem Informasi Geografis," in Seminar Nasional Geomatika, 2018, 2019, pp. 547-554.

[3] Nandi, "Promoting Sustainable Development in Spatial Planning of Bandung City," in International Conference on the Future of Urban and Peri-urban Area, 2011, pp. 280-288. 
[4] W. Pradoto, F. H. Mardiansjah, O. R. Manullang, and A. A. Putra, "Urbanization and the Resulting Peripheralization in Solo Raya, Indonesia," IOP Conf. Ser. Earth Environ. Sci., vol. 123, pp. 0-9, 2018.

[5] M. C. O. G. and D. Spence et al., Growth Commission: Urbanization and Growth. 2009.

[6] A. M. Fazaalloh, "Urbanisasi , Industrialisasi , Pendapatan , dan Pendidikan di Indonesia," Habitus J. Pendidikan, Sosiologi, dan Antropol., vol. 1, pp. 16-23, 2017.

[7] P. Tjiptoherijanto, "urbanisasi dan pengembangan kota indoi=12484-24709-1-PB (1)," Urban. Dan Perkemb. Kota Indones., vol. 10, no. 2, pp. 57-72, 1999.

[8] R. Hu, "Drivers of China's Urbanisation and Property Development," Australas. J. Reg. Stud., vol. 19, no. 2, pp. 156-180, 2013.

[9] J. Xiao et al., "Evaluating urban expansion and land use change in Shijiazhuang, China, by using GIS and remote sensing," Landsc. Urban Plan., vol. 75, no. 1-2, pp. 69-80, 2006.

[10] H. Hussain, N. H. M \& Byrd, "Malaysia , Urbanization and De-industrialization : Does Malaysia have the Land Capacity for De-urbanization?”, 2012.

[11] R. Jedwab et al., "Demography, Urbanization and Development Rural Push, Urban Pull and Urban Push?," Work. Paper, vol. 15, p. 32, 2014.

[12] R. Jedwab, L. Christiaensen, and M. Gindelsky, "Rural Push, Urban Pull and ... Urban Push ? New Historical Evidence from Developing Countries *," no. January, 2014.

[13] BPS, Statistik Indonesia 2018. Jakarta: BPS, 2018.

[14] J. Martinez-vazquez, "Urbanization and the Poverty Level," International Study Program Work. Paper. Ser. June 2014, pp. 1-47, 2009.

[15] BPS, Potret Pendidikan Indonesia. Jakarta, 2018.

[16] The Assistance Team on Fiscal Decentralization for the Minister of Finance, Indonesia's Intergovernmental Transfer Response on Future Demographic and Urbanization Shifts, Jakarta, 2011.

[17] N. M. O. H. M. Savitri, "Pengaruh Infrastruktur Terhadap Pertumbuhan Ekonomi di Indonesia,” Buletin Ekonomi Moneter dan Perbankan, pp. 61-98, 2014.

[18] BPS, “Laporan Perekonomian Indonesia 2018,” Jakarta, 2018.

[19] Kementrian Perindustrian, Analisis Perkembangan Industri Edisi II - 2018. Jakarta, 2018. 